Vol. 1 No. 1, February 2022

e- ISSN 2828-0601, p-ISSN 2828 - 0695

Available online at:

Journal of Classroom

Action Research

https://journal.eltaorganization.org/index.php/jcar

\title{
Improving Students' Achievement In Descriptive Text Through the Application (STAD) Student Team Achievement Division
}

\author{
Sahat Tua Manalu \\ Faculty of Cultural Sciences, Universitas Sumatera Utara \\ $\underline{\text { sahatmanalu319@yahoo.co.id }}$
}

\begin{abstract}
This study aims at improving students' descriptive paragraph writing through STAD(Student Team Achievement Division) technique. In this study the writer conducted classroom action research. The subject of the research was 40 students of grade X SMA Negeri 1 PEGAJAHAN. Districts of Pegajahan Serdang Bedagai. There are four parallel classes that consist 40 students each class. The instruments for collecting data were writing test for quantitative data, qualitative data and questionnaire sheet,. The instrument for collecting the quantitative data was writing test while the qualitative data were gathered through the interview, diary notes and observation sheet. The qualitative data showed that the students were not interested in descriptive text. Based on the students' scores of class x-1 taken by the English teacher for twice, it was gained that only $40 \%$ and $42 \%$ of students achieve .The minimum Completeness Criteria in writing. More than $50 \%$ of students are not able to get it.It means the ability of students is low. In this school students must achieve 70 in order to get in English subject. After having been analysed, the result of the study denotes that the students' achievement constantly improved significantly. In conclusion, the application of Student Team Achievement Division technique can improve the students' achievement in writing descriptive text.
\end{abstract}

\section{Keywords: Classroom Action Research Descriptive. STAD (Student Teams Achievement Division)}

\section{Introduction}

Cooperative learning provides the opportunity for students to interact. Students who share reviews their understanding of a concept friends are actually experiencing a learning process that is effective and can maximize learning outcomes far more advantage than if he was listening to the teacher's explanations. Cooperative learning is a teaching methodology that offers "principles and techniques for helping students work together more effectively" (Jacobs, Power, \&Loh, 2002, p. ix). In other words, cooperative learning is much more than just putting students together in groups and asking them to work together. Instead, cooperative learning principles help us understand what is involved in helping groups succeed, and cooperative learning techniques embody those principles in an attempt to provide structure for student interaction (Baloche, 1998, Johnson \&Johnson, 1999)

In learning English, the students are required to master four aspects of language, they are, listening, writing, reading, and writing. Mastering language skills is aimed at guaranteeing that all students have a good working command of English as their working command of English may diverse due to their English learning experience. The ability to communicate in globalized era, the capability is writing English is highly needed. 
English language teaching has been known the four skills: listening, speaking, reading and writing (Brown, 2001:232). Those skills are communication skills that are important in all subject areas in the curriculum(Walberg, 2004:7).

Writing is a written communication which must have something on it,it is information. It can be not easy as it has to engage with grammar, vocabulary, spelling, organizational sturucture of genre and even mechanics (punctuation, etc). Writing instruction must deal with many issues, such as how to determine the importance of correct spelling and punctuation in early drafts, how to treat the different steps in the composition process, and how to analyze a text for its context and purpose ( Yan, 2005:18).Writing is about delivering information without seeing readers. No matter how long the paragraphs, if readers can't find any information on that writing,

Based on the writer's experience when he was in teaching field practice program in SMANegeri 1 Pegajahan Serdang Bedagai Regency, many students admitted that they were not competent in writing skill because ofsome difficulties. Writing activity was not attractive to them because they did it just by themselves, everyone were busy with their own writing and there was no interaction among of them. Most of them spent ten to fifteen minutes to only thinking about the idea of the story. The remining time was used to look for words in the dictionary, while grammar and punctuation definitely was no longer be a part of their attention anymore.This condition was such a boring process where they could become passive.

It was predictable when the writer checked the students written product, there were so many corrections, even the writer could not get the idea of what the students had written. The students had already predicted that they would get low score. Similary, based on an observation, the students in SMA N 1 Pegajahan admitted the same thing. They even mostly disliked writing activity because they considered that writing was such a boring activity though they admitted that they were not really good in grammar, vocabulary and spelling.

The writer indicated that the studentsin SMA N 1 Pegajahan need an active teaching strategy which can change writing in students' perspective became an exciting writing. This is to establish the students'interesting and curiosity in writing English by which they were expected to be competent and competitive.

Based on students syllabus, Descriptive text was taught in grade tenth, but students of SMA Negeri 1Pegajahan have not finished learning the descriptive text. Descriptive texts are parts of human daily live (Lusiana, 2013)

The purpose of a descriptive text is to describe a particular person /thing. To improve the students' achievement in writing Descriptive text, the writer was going to use STAD (Student Team Achievement Division) method. Once students in SMA N 1Pegajahan admitted that writing was passive, the writer offers an active strategy that was STAD (Student Team Achievement Division).

Due condition above, teacher English teacher needs to solve the problem by applying an apporite approach, method, strategy or technique of learning. In this study, the writer did a try out on the application of Student Team Achievement Divisions (STAD) technique to improve the students writing achievement especially in descriptive text. The other reason why th writer choose the media for teaching writing is it trains the students memorizing the words.

The other reason why the writer choose the media for teaching writing is ittrains the students memorizing the words. The writer also interested with the study about Student Teams Achievement Divisions (STAD).

STAD is more effective in cooperative learning methods for improving students learning of clear objective in language rules and skills. In general, teachers create and use STAD in their classrooms to the development of reading, writing, and spelling skills. The writer hopes the students 
can be increased the achievement of their English writing, without depending on dictionary and the word meaning from the teacher. STAD are interactive media in the classroom to support studying listening, speaking, reading and writing.

\section{Literature Review}

It has been stated in the previous that writing is not an easy skill to be achieved. It is not only experts argue it, but also the students who are directly engaged with the process of reaching the accomplishment by the learning and teaching activity. Dominantly, students admitted that they dislike writing because there, in writing, they could be very passive as it did not allowed them to discuss with friends in which every single person did their own writing and no movements. In fact, they still must face their less vocabulary and grammar or even mechanics of their writing.

There are nine kinds of cooperative learning to create a classroom environment that encourages students to learn.

\section{Writing}

Writing is a process of formulating and organizing ideas in appropriate to deliver the aim and present them on a piece of paper.According to Jones in R .Cooper and Odell (1977:33)writing is synonymous with discourse, and it is discussed in terms of aims, it relates to the function of language, and in terms of its feature, which are separate element, devices, mechanism of language.

Writing is one of the language skills to convey thoughts, ideas ,desires and feeling, which performed through written forms. Breton (1982:2)assert that writing differs from speaking. While Heaton (1998:135) says writing is the ability to use structure. writing refers to the skill of using graphic symbols which have to be arranged to certain convention .It means that writing is an act of skill in forming graphic symbols and combining a number of diverse element, so we describe that writing is a whole brain activities to formulate and organize ideas in correct words to convey and communicate the objects to the reader .

\section{The Genre of Descriptive}

The genre of describing is one of the fundamental functions of any language system and one of the first skills emergent language-users learn to control. It is also one of the most widely used genres across all of the learning areas,. Description enables the category or classification of an almost infinite range of experiences, observations and interactions into a system that orders them for immediate and future reference, and allows us to know them either objectively or subjectively, depending on the learning area or intent of the writer. Describing is also used extensively in many text types. such as information

Descriptive text was a piece of writing that was intended to convey meaning to the reader through sensory details and provides image to the reader. Pardiyono (2007:34)state that description paragraph was a type of written text paragraph, in which has the specific function to describe about object and it has the aim that was giving description of the object to the reader clearly.

\section{Generic Structure of Descriptive Text}

Which was divided in to two they are: a. identification: identifies the phenomena on to be described and b. description: describe parts, qualities, characteristics, condition qualities.

\section{Grammatical -Features Of Describing}

When describing things from a technical or factual point of view, the present tense is predominantly used; for example, has, eats, sings, lays, swim

Although present tense may be used in literary descriptions, it is past tense that tends to dominate;

Published by English Lecturers and Teachers Association (ELTA)

Copyright (C) 2022, authors 
for example, had, was, enjoyed, seemed, sparkled

Relational verbs are used when classifying and describing appearance/qualities and parts/functions of phenomena (is, are, has, have); for example,

My favorite toy is a teddy bear because it is cuddly and friendly. It is my friend too. Turtles do not have teeth, they have a sharp beak instead. Eric the Red is an old man. Eric the Red has a greatcoat.

Action verbs are used when describing behaviours/uses; for example,

An ant has three body parts.

Some ants have wings.

The queen ant lays the eggs.

Ants live in colonies.

In literary and commonsense descriptions, action verbs are used metaphorically to create effect; for example,

Mia bubbled with enthusiasm. Declan smashed therecord.

Mental verbs are used when describing feelings in literary descriptions; for example,

She feltunhappy. He liked dancing.

Adjectives are used to add extra information to nouns and may be technical, everyday or literary, depending on the text; for example,
Possums are nocturnal.
Technical
It is grey and brown.
Everyday
Her appearance was majestic.
Literary

Adjectives can be used on their own, as above, or as part of a noun group, as below:Turtles are covered with a hard, box - like shell.

chnical

He has a cool hairstyle.

His luminous, dark coat gave him an eerie quality.

Everyday

Literary

Often adjectives used in literary descriptions can be considered to be affective due to the emotive impact they have on readers. This can also be the case with the way that some verbs and adverbs are used.

Adverbs are used to add extra information to verbs to provide more detailed description; for example,

Turtles swim slowly.

She was always hassling her mother.

He could think clearly.

Adverbial phrases are used in descriptions to add more information about the manner, place or time; for example,

Walruses have hair on their lips. Place

The student only worked diligently just before exams. Times

Literary descriptions use a range of devices to create effects such as similes, metaphors, personification and alliteration; for example, 


\section{Student Team Achiement Divisions (STAD)}

Therefore, there is a need to study cooperative learning technique used in this study will be the students Achievement Divisions method develop by Slavin, (1986). STAD has been described as the simplest of group of cooperative learning technique referred to as Student team learning method. In the STAD students are assigned to four or five member teams reflecting a heterogeneous grouping high, average, and low achieving students of diverse ethnics backgrounds and different genders.

Each week, the teacher introduces new material through a lesson, class discussion or some form a teacher presentation. Team members then collaborate on worksheets designed to expand and reinforce the material taught by teacher Team member may (a) work on worksheets in pairs, (b) take turn quizzing each other, (c) discuss problems as group or (d) use whatever strategies they are to learn the assigned material.

\section{The Steps of STAD Technique}

a. Students are divided into several groups. Each group consists of 4-5 people. The group should consist of students from diverse backgrounds, for example in terms of achievement, gender, ethnicity, religion, etc.

b. Teachers discuss the topic of learning, for example: My dog.

c. The teacher gives the task to the group to practice / discuss an advanced topic together. Here, members of the group work together.

d. The teacher gives a quiz / questions / test to all students. At the time of answering the quiz should not help each other.

e. The test results are scored. The score for each student is determined by the score / improvement of each member of the group.

\section{Methodology}

The subjects of the research were the students of Grade tenth in SMANegeri 1 Pegajahan Regency of SerdangBedagai.. This study would be conducted in a class X-1 which consisted of 40 students. The sample of the research would be obtained by using total sampling.

This study applied Classroom Action Research because the problems was found in the classroom and would be solved in the classroom which also deal with improving students' achievement in writing descriptive text by applyingStudent Team Achievement Devision. Wallace (1988: 4) said that action research is an observation of an activity that appears consciously in a class. Action Research is a process, in the sense that the process can be repeated ( reframing the problem, collecting fresh data, rethinking our analysis, etc) until we have found a solution that satisfies us. Action research was type of research insider investigation by researcher, in thceir own area as a focus for their studies. The process of ation research was reflective, deliberate and systematic.

In CAR, there were four phases each of cycle, namely: 1) planning, 2) action, 3) observation, 4) reflection. The teacher would start by doing Cycle I.CycleI was conducted in three meetings. If the result fails or not significantly improved, it would be continued to next cycle named cycle II by renewing the previous steps to solve the problems. The new cycle would improve the teaching decision. If the new planning improved the students' achievement in writing descriptive text.

In this research the data was collected by Quantitative and Qualitative ways. Quantitative data was broadly used to describe what could be counted or measured and could therefore be considered 'objective'. The data was collected through test which was administrated by the teacher. The qualitative was used to describe data which were not amenable to being counted or measured in 
an objective way, and was therefore 'subjective'. This study gathered the data by using diary note, interview, and the observation sheet. In analyzing it, the quantitative data was analyzed by calculating the score of the students' writing test. The qualitative data was analyzed from dairy notes, observation sheet, and interview sheet to describe the improvement of students' achievement in writing Student Team Achiement Divisions (STAD) text by the application of.). STAD (Student Team Achievement Division)

For the scoring of the tests result, the researcher used a scroing rubric. A scoring rubric acts as a useful guide for evaluating the quality of students'writting response (Becker:2011). The components which would be scored will bedescribed as follows:

\section{Table 1 Scoring}

\begin{tabular}{llc}
\hline \multicolumn{1}{c}{ Components } & Score \\
\hline $\begin{array}{l}\text { Generic Structures } \\
\text { a. Identification }\end{array}$ & 20 & 10 \\
b. Description & & 10 \\
\hline $\begin{array}{l}\text { Language Features } \\
\text { a. The use adjective and compound }\end{array}$ & 40 \\
$\quad$ adjective & & 15 \\
b. The use of linking verbs & 15 \\
c. The use of attribute has and have & 10 \\
\hline Grammar and Vocabulary & 20 & \\
\hline Mechanics & 20 & 5 \\
a. Spelling & & 5 \\
b. Punctuation & & 10 \\
c. Acuracy & 100 & \\
\hline Total &
\end{tabular}

There would be three writing descriptive tests by which the mean of each test would becounted. The mean of each test would be used as the guidance to make a conclusion

\section{The Procedure of Collecting Data}

The type of the data which is received consists of:

1. The result of the study as quantitative data 2.The result of observation as qualitative dataThe students were asked to do written test by giving their opinions about the topics they got. The qualitative data were taken from questionnaire Thus, research was managed in one class with 40 samples. The research was accomplished in two cycles. Every cycle consisted of four steps of action research (planning, action, observation and reflection). The first cycle managed in three meetings so there were six meetings altogether. They were tested three times; namely test I in the first meeting of cycle I, test II in the third meeting of cycle I, and test III in the third meeting of cycle II. From the entire test and the teaching process managed, it was found that the students' score kept improving from the test I to the test II and III. The students' score in the test I was lower than test II, the test II was lower than post-test III. Students' writing was score by calculating four component scales: accuracy, cleary, content, and supporting aids. The students were regarded accomplishing the test if they got score at least 70 .

\section{Findings and Discussion}

The data were taken from only one class of SMA N 1 Pegajahan. Pegajahan District The first grade ( $\mathrm{x}-1)$ which consisted of 40 students. The writer took all the students who from the first until the last meeting. The teaching process of writing descriptive text was done by using STAD (Student Team Achievement Division) 
The Quantitative Data

Table 2 The improvement Percentage of Students who got score 75 to up in Writing

\begin{tabular}{lc}
\hline \multicolumn{1}{c}{ Test } & Percentage \\
\hline Orientation test & $\mathbf{0 \%}$ \\
Cycle I & $\mathbf{5 0 . 0 0 \%}$ \\
Cycle II (Test I) & $\mathbf{7 0 . 0 0 \%}$ \\
Cycle III (Test III) & $\mathbf{8 3 . 5 0 \%}$ \\
\hline
\end{tabular}

Based on the information above, the range could be calculated as follows:

Range $=$ the highest percentage - the lowest percentage

$=100 \%-0 \%$

$=100 \%$

\section{The Qualitative Data \\ Questionnaire}

This strategy can also be shown that the ability of each student who rarely occurs when learning in the up -to -date style was gradually displayed through the encouragement of the groupBased on the result of questionnaire scores, it was obtained that STAD (Student Team Achievement Division) was helpful for most students. They comprehenced how to make descriptive text. Based on the data, it can be concluded that most students strongly agreed was useful and applicable in writing.

\section{Conclusion}

After analyzing the data, it can be concluded the students' achievement in writing descriptive text is significantly improved by the application of Student Team Achievement Divisions (STAD)strategy. The improvement of students' achievement in writing report text by applying Student Team Achievement Divisions (STAD) strategy was supported by the mean scores which were also increased test by test and it can also be seen from the percentage of the number of the students who can reach the Minimum Score Criteria (KKM). Encouragement from members of the group was able to cultivate a sense of confidence students, that he is able to contribute ideas that useful for solving task

It is suggested that : (1) applying STAD technique in writing descriptive text is very helpful by STAD the students learnab out how give describe and make the describe (2) the students are suggested apply in STAD in learning English especially in descriptive text so the students can write better (3) the English teacher are advised to use this strategy

\section{References}

Brown, H, Douglas. (2001). Teaching by Principles; An Interactive Approach to Language Pedagogy. 335. New York. Longman

Dirgayasa, I.W. (2012). Maritime English Writing. Medan: Unimed Press

Gintings, E.M.. (2011). Improving The Students' Achievement In WritingStudent Team Achiement Divisions (STAD) Text Through Number Heads Together Technique.Medan. State University of Medan

Halliday and Hasan, (1976).Expression and Meaning To CTL. London: Sage Publications 
Journal of Classroom Action Research (JCAR), Vol. 1 No. 1, February 2022. e-ISSN 2828-0601, p-ISSN 2828-0695

Harmer, J. (1998).How to teach English: an introduction to the practice of English language teaching. New York: Longman.

Harmer, J. (2003).The Practice of English Language Teaching. Malaysia :Longman.

Harmer, J. (2007).How to Teach Writing. England: Longman

Martin, B. (2000). Living education: Action research as a practical approach to congregational education. North American Baptist College.

Miller, C.A. (2007). Action Research: Making Sense of Data. Academic Journal, 1 (1), 9-28

Sudarwati, M, and Geace, E. (2007).Look Ahead An English Course 2. Jakarta: Erlangga

Walacce, M.J. (.2001). .Action research for Language teachers. Cambridge University Press 